\title{
Effects of Concentration, Molecular Weight, and Exposure Time of Poly(ethylene glycol) on Cell Fusion
}

\author{
Naoki NaKaJIMA and Yoshito IKadA* \\ Research Center for Biomedical Engineering, Kyoto University, 53 Kawahara-cho, \\ Shogoin, Sakyo-ku, Kyoto 606, Japan
}

(Received April 13, 1994)

\begin{abstract}
Membrane fusion of $\mathbf{L}$ cells and L929 cells was studied in a monolayer using poly(ethylene glycol)(PEG) with eight different molecular weights at varying concentrations. All PEG specimens were free of additives. Cell fusion did not come to completion immediately upon contact with PEG solution, but gradually continued during postincubation. The frequency of membrane fusion increased with increase in the cell density seeded in the culture plate and time of exposure to the PEG solution. Further, with increasing PEG concentration the frequency of fusion markedly increased, regardless of the PEG molecular weight. However, fusion was practically not observed at PEG concentrations lower than $30 \mathrm{w} / \mathrm{w} \%$, suggesting that cell fusion is triggered by a physicochemical event associated with the interaction between the cell membrane and PEG molecules. It is likely that the optimum molecular weight of PEG for membrane fusion is around 1000 , irrespective of the PEG concentration and the cell type used, though the extent of fusion differs according to cell type. No concerted effect of the molecular weight of PEG was observed on fusogenic ability when mixtures of low and high molecular weights of PEG were used.

KEY WORDS Membrane Fusion / Poly(ethylene glycol)(PEG) / Fusion Index / Binucleate / Multinucleate /
\end{abstract}

One of the most remarkable consequences of cell membrane-membrane interactions is cell fusion. It occurs artificially as well as naturally on a subcellular level, e.g., in fertilization, virus invasion into cell, giant cell formation, and endo- and exocytosis.

Cell fusion techniques have attracted much attention in the in vitro system including hybridoma preparation for monoclonal antibodies, which is very familiar in cell and gene technologies. In fact, numerous cell treatment methods have been reported to effectively induce cell fusion including viral promotion, ${ }^{1,2}$ electrical stimulation ${ }^{3}$ and addition of chemicals. Among these treatments, cell fusion promoted by chemicals, particularly by poly(ethylene glycol) (PEG) addition, has been most widely investigated ${ }^{4-14}$ and the technique has been improved, ${ }^{6,15-22}$ because this technique is very convenient owing to easy handling, low biohazard, and wide applicability. On the other hand, it has been reported that other chemicals induced membrane fusion, such as fatty acids, ${ }^{23}$ lysolecithin, ${ }^{24}$ oxygen, ${ }^{25}$ and polycations. ${ }^{26-28}$

A large number of studies have been carried on the mechanism of membrane fusion by PEG using liposomes, ${ }^{4,5,29,30}$ SEM, ${ }^{31,32}$ fluorescent probe, ${ }^{33-35}$ spin label technique, ${ }^{36}$ and NMR, ${ }^{31}$ but all reports have focus entirely on changes in cell or liposome membranes during fusion and few reports are on the fusion mechanism from the standpoint of physicochemical properties of PEG. Maggio et al. found that PEG reduced markedly the surface potential of liposome, resulting in an in-

\footnotetext{
* To whom correspondence should be addressed.
} 
crease in fusogenic ability. ${ }^{13}$ Arnold et al. reported that the dielectric constant of water is reduced drastically on addition of $\mathrm{PEG},{ }^{37}$ while Blow et al. point out a strong interaction of PEG with water by differential scanning calorimetry. ${ }^{38}$ However, few explanations were proposed on why PEG has been exclusively used as a fusogen compared with other chemicals.

In this study we attempt first to learn the influence of physicochemical properties of PEG on cell fusion. Although the effect of PEG concentration and its molecular weight was already investigated by Davidson et al. ${ }^{7}$ and Lane et al., ${ }^{10}$ they used an unpurified and different source of PEG. Contamination of commercial grade of PEG was pointed out by Honda et al. ${ }^{39}$ Smith et al., ${ }^{14}$ and Kadish and Wenc. ${ }^{8}$ It is, therefore, doubtful that the results of Davidson et al. ${ }^{7}$ and Lane et al. ${ }^{10}$ really reflect the exact molecular properties of PEG on cell fusion. In the present study we used purified and uncontaminated PEG and studied the effect of experimental conditions such as cell density, PEG concentration, molecular weight of PEG, PEG exposure time, and postincubation time. In addition, since no one has investigated the effects of molecular weight distribution of PEG, we examine the influence of molecular weight distribution using a mixture of PEG having two different molecular weights.

\section{MATERIALS AND METHODS}

\section{Cell Culture}

The strains used in our study are L cells and L929 cells, both established mouse fibroblast cell lines. For comparison, HeLa and 3T3 cells were also used. Cell culture was made with Eagle's MEM(EMEM) in tissue culture dishes of $10 \mathrm{~cm}$ diameter at $37^{\circ} \mathrm{C}$ and $5 \% \mathrm{CO}_{2}$ under moisture. EMEM was supplemented with $0.25 \mathrm{w} / \mathrm{v} \%$ sodium hydrogen carbonate, 0.03 $\mathrm{w} / \mathrm{v} \%$ l-glutamine, and $10 \mathrm{v} / \mathrm{v} \%$ fetal bovine serum (FBS). Fusion was carried out in a monolayer according to the method reported by Davidson and Gerald. ${ }^{6}$ Semiconfluent cells in a logarithmic growth state were rinsed with EMEM without FBS and trypsinized with $0.25 \mathrm{w} / \mathrm{v} \%$ trypsin and $0.02 \mathrm{w} / \mathrm{v} \%$ EDTA $-2 \mathrm{Na}$ in PBS(-) for $5 \mathrm{~min}$ at $37^{\circ} \mathrm{C}$ and the suspension was transferred to a $50 \mathrm{ml}$ centrifuge tube supplemented with the same volume of EMEM to deactivate trypsin. After centrifugation at $1000 \mathrm{rpm}$ for $5 \mathrm{~min}$, the cells were resuspended in EMEM to a concentration of $1.5 \times 10^{5}$ cells $\mathrm{ml}^{-1}$. After gentle stirring for $10 \mathrm{~min}$, exactly $2.0 \mathrm{ml}$ of suspension were added to a 24 well multidish tissue culture plate (Corning, N.Y., U.S.A.) drop by drop under mild stirring. After letting the cells settle longer than $2 \mathrm{~h}$, they were incubated at $37^{\circ} \mathrm{C}$ for $24 \mathrm{~h}$. This procedure for cell seeding was essential for the uniform distribution of cells in the plate which allowed us to quantitatively evaluate the extent of cell fusion. During incubation, the cells attached to the plate and well spread out.

\section{Preparation of PEG Solution}

PEG with molecular weights of 200, 400, $600,800,1000,2000,3000$, and 5000 were supplied by Daiichi Kogyo Seiyaku Co., Ltd., Kyoto, Japan. They are abbreviated here as PEG 200, PEG 400, PEG 600, PEG 800, PEG 1000, PEG 2000, PEG 3000, and PEG 5000. The polymers were free of additives such as antioxidant, possessed a hydroxy group at each chain terminal and used without further purification, unless otherwise noted. Examples of gel permeation chromatograph of PEG specimens are shown in Figure 1. The ratio of weight-average molecular weight $\left(\bar{M}_{w}\right)$ to number-average molecular weight $\left(\bar{M}_{n}\right)$ was within 1.2 for all polymers. Therefore, we use simply the term molecular weight instead of $\bar{M}_{w}$ and $\bar{M}_{n}$ unless otherwise specified. PEG was dissolved in EMEM without FBS at various concentrations from 10 to $60 \mathrm{w} / \mathrm{w} \%$ at room temperature and used for fusion without sterilization. To compare mono- and multidispersed molecular weights of PEG, mixtures 


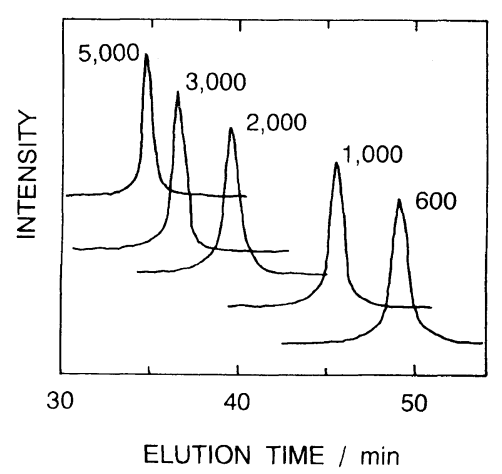

Figure 1. Representative gel permeation chromatogaphs of PEG specimens with different molecular weights. Carrier phase, chloroform.

of PEG 400, and PEG 5000 were prepared in various weight proportions.

\section{Cell Fusion}

EMEM was aspirated from the culture dishes containing cells and $0.2 \mathrm{ml}$ of PEG solution was added. Following exposure to the PEG solution for given periods at room temperature, the cells were rinsed three times with $2.0 \mathrm{ml}$ of EMEM without FBS at $37^{\circ} \mathrm{C}$ to remove $\mathrm{PEG}$ solution as much as possible and then $1.0 \mathrm{ml}$ of new EMEM was added. After further incubation at $37^{\circ} \mathrm{C}$, the cells were fixed with $2.5 \mathrm{v} / \mathrm{v} \%$ glutaraldehyde in EMEM without FBS at $4^{\circ} \mathrm{C}$ for $24 \mathrm{~h}$ and stained with Mayer's hematoxylin. Finally, the stained cells were photographed randomly choosing approximately 500 cells per field. Two pieces of picture were taken for each well and the results on 3 wells were averaged for every sample. The fusion index was defined by the following equation as a function of nucleus number.

Fusion index $(\%)=$

$$
\frac{\text { total number of nuclei in fused cells }}{\text { total number of nuclei in all the cells }} \times 100
$$

The fraction of binucleate cells was estimated as (total number of nuclei in binucleates)/(total number of nuclei in all fused cells).

The following culture conditions were used here as the standard for cell fusion: the initial cell density $=1.5 \times 10^{5}$ cells cm $^{-2}$, exposure time to PEG solution $=1 \mathrm{~min}$, incubation time after PEG treatment (postincubation time)= $2 \mathrm{~h}, \mathrm{PEG}$ and molecular weight $=\mathrm{PEG} 3000$, and concentration of PEG solution, $40 \mathrm{w} / \mathrm{w} \%$.

\section{Statistical Analysis}

Variation of data was expressed using standard error (SE). In the case of $n=6$, the probability is $63.7 \%$ that real average of its mother population exists in area of data average $\pm S E$. T-test was carried out to evaluate the statistical significance of difference in the two experimental systems. Each of average data was compared by the $t$ distribution function with $95 \%$ confidence after each standard deviation was by the $F$ distribution function.

\section{RESULTS}

\section{Stainability of Cell Nuclei}

Light microphotographs of L cell and L929 cells are given in Figure 2, together with those of HeLa and 3T3 cells. In accordance with general observation, $L$ cells have slim and long pseudopods, whereas L929 cells have relatively short pseudopods and spindle shape. Both cells showed the same doubling time $(21 \mathrm{~h})$ when incubated, but $\mathrm{L}$ cells were attached to the culture plate and spread out more rapidly than L929 cells. A typical microphotograph of L929 cells after membrane fusion is given in Figure 3. Hematoxylin was capable of selective and effective staining of the nuclei of $L$ cells and L929 cells and thus it was possible to distinguish fused cells from unfused and hence evaluate the fusion index as a function of cell nucleus number. The stainability of $L$ cells was similar to that of L929 cell, but HeLa and 3T3 cells could not be so clearly stained as L cells and L929 cells, as is seen in Figure 2. Thus only L cells and L929 cells were used for the fusion study. 

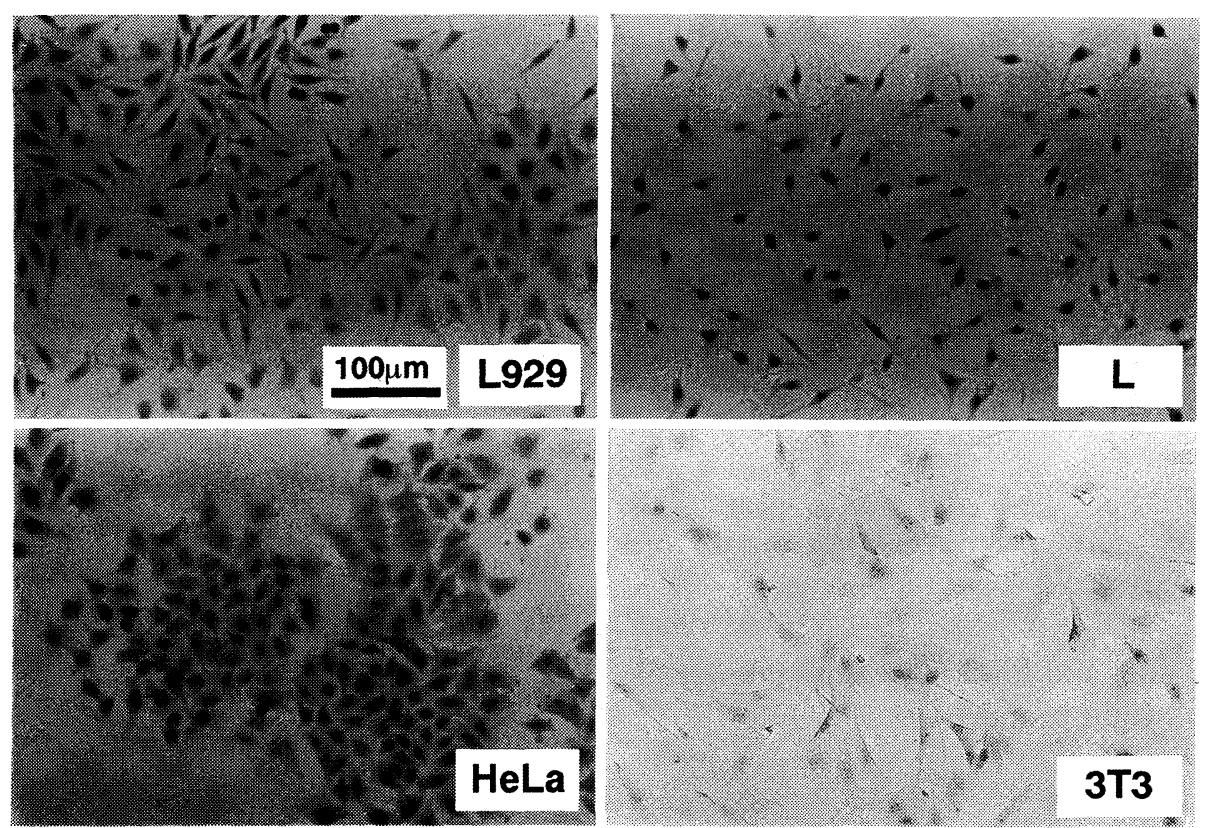

Figure 2. Light micrographs of L929, L, HeLa, and 3T3 cells after staining with hematoxylin. 3T3 cells were cultured in Dalvecco modified MEM and others in Eagle's MEM.

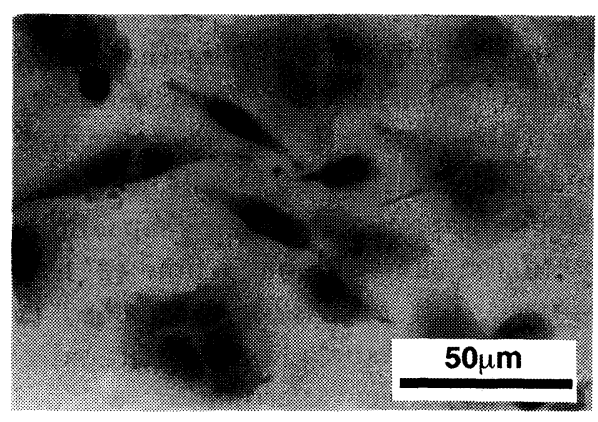

Figure 3. Light micrographs of L929 cells treated with PEG 3000 at $40 \mathrm{w} / \mathrm{w} \%$. Cell density, $1.5 \times 10^{5}$ cells cm $^{-2}$; exposure time, $1 \mathrm{~min}$; postincubation time, $2 \mathrm{~h}$. Cells were stained with hematoxylin.

\section{Time Effects}

It is likely that at least three parameters affect cell fusion by PEG in the monolayer system, irrespective of the molecular weight and solution concentration of PEG: cell density, PEG exposure time and postincubation time. The effects of the density of L929 cells in the culture dish on cell fusion is given in Figure 4.

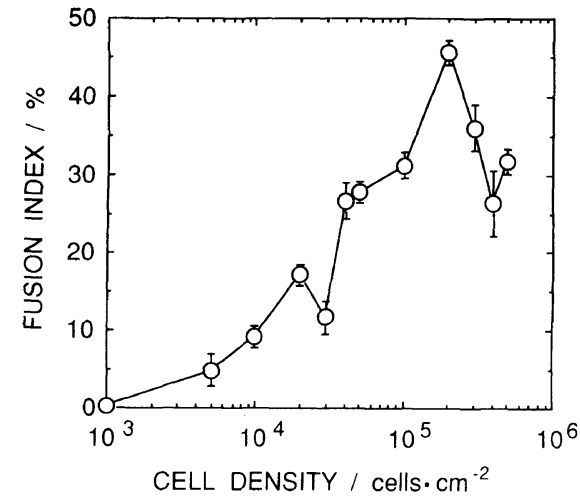

Figure 4. Effects of the density of L929 cells on the fusion index when seeded in 24 well tissue culture dishes and treated with PEG 3000 at $40 \mathrm{w} / \mathrm{w} \%$. Exposure time, $1 \mathrm{~min}$; postincubation time, $2 \mathrm{~h}$. Error bars show the standard error $(n=6)$.

The other parameters than cell density were fixed to the standard culture conditions as described in Materials and Methods. The fusion index markedly increased with cell density, but decreased at higher density than 


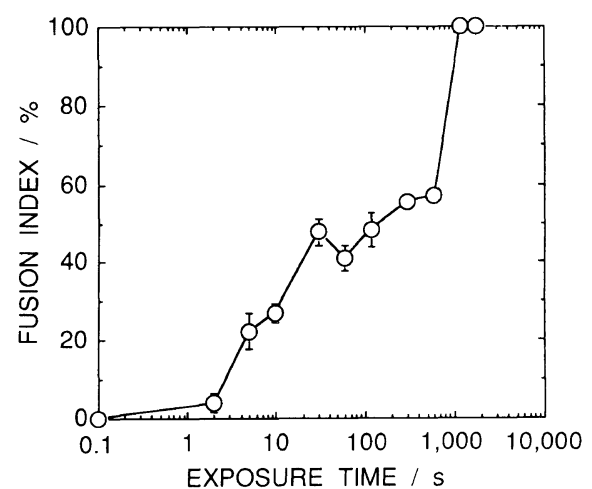

Figure 5. Effects of exposure time on the fusion of L929 cells treated with PEG 3000 at $40 \mathrm{w} / \mathrm{w} \%$. Cell density, $1.5 \times 10^{5}$ cells $\mathrm{cm}^{-2}$; postincubation time, $1 \mathrm{~min}$. Error bars show the standard error $(n=6)$.

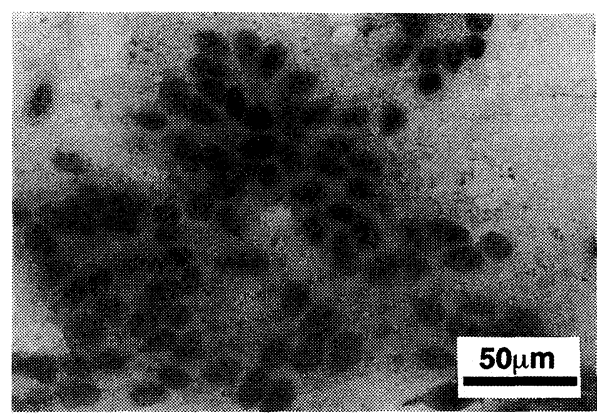

Figure 6. Excessive membrane fusion of L929 cells treated with PEG 3000 at $40 \mathrm{w} / \mathrm{w} \%$. Cell density, $1.5 \times 10^{5}$ cells $\mathrm{cm}^{-2}$; exposure time: $20 \mathrm{~min}$; postincubation time, $2 \mathrm{~h}$. Cells were stained with hematoxylin.

$2 \times 10^{5}$ cells $\mathrm{cm}^{-1}$ after passing through a maximum. For the following experiment, the cell density was fixed at $1.5 \times 10^{5}$ cells cm $^{-2}$.

The influence of the time of exposure to PEG solution on cell fusion is shown in Figure 5, when the other parameters than that were fixed to the standard culture conditions. Apparently, the fusion index increased steeply with time, but further exposure to PEG led to overfusion. A representative microphotograph of multinucleate formation is given in Figure 6. Such overfusion frequently resulted in cell death, probably caused by long interactions between PEG molecules and the cell membrane. Thus,

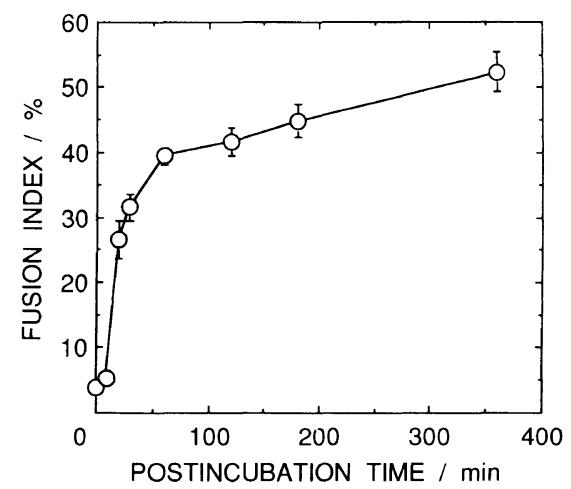

Figure 7. Effects of postincubation time on the fusion of L929 cells treated with PEG 3000 at $40 \mathrm{w} / \mathrm{w} \%$. Cell density, $1.5 \times 10^{5}$ cells $\mathrm{cm}^{-2}$; exposure time, $1 \mathrm{~min}$. Error bars show the standard error $(n=6)$.

1 min was the exposure time to PEG for a normal culture. Figure 7 shows the effects of postincubation time after PEG exposure on cell fusion. Glutaraldehyde was added to the cell culture medium by $2.5 \mathrm{v} / \mathrm{v} \%$ to stop cell fusion and morphological change. Similar to PEG exposure, prolongation of postincubation resulted in increased fusion index. Figure 8 shows time course of the cell morphological change. At least $10 \mathrm{~min}$ is necessary for significant morphological change to occur. This indicates that membrane fusion does not come to completion instantly upon exposure to PEG solution but gradually proceeds with time.

\section{Effects of PEG Molecular Weight and Solution Concentration}

Figures 9 and 10 showed the fusion index values plotted against molecular weight for $\mathrm{L}$ cells and L929 cells, respectively. PEG concentration was changed from 30 to $60 \mathrm{w} / \mathrm{w} \%$. Both cell lines exhibit almost the same profiles for the fusion index. Remarkable increase in the fusion index with increasing concentration of PEG (no fusion occurred at PEG concentrations lower than $30 \mathrm{w} / \mathrm{w} \%$ (data not shown) and optimum molecular weight of PEG for cell fusion around 1000 were noted. Lower or higher molecular weights than 1000 

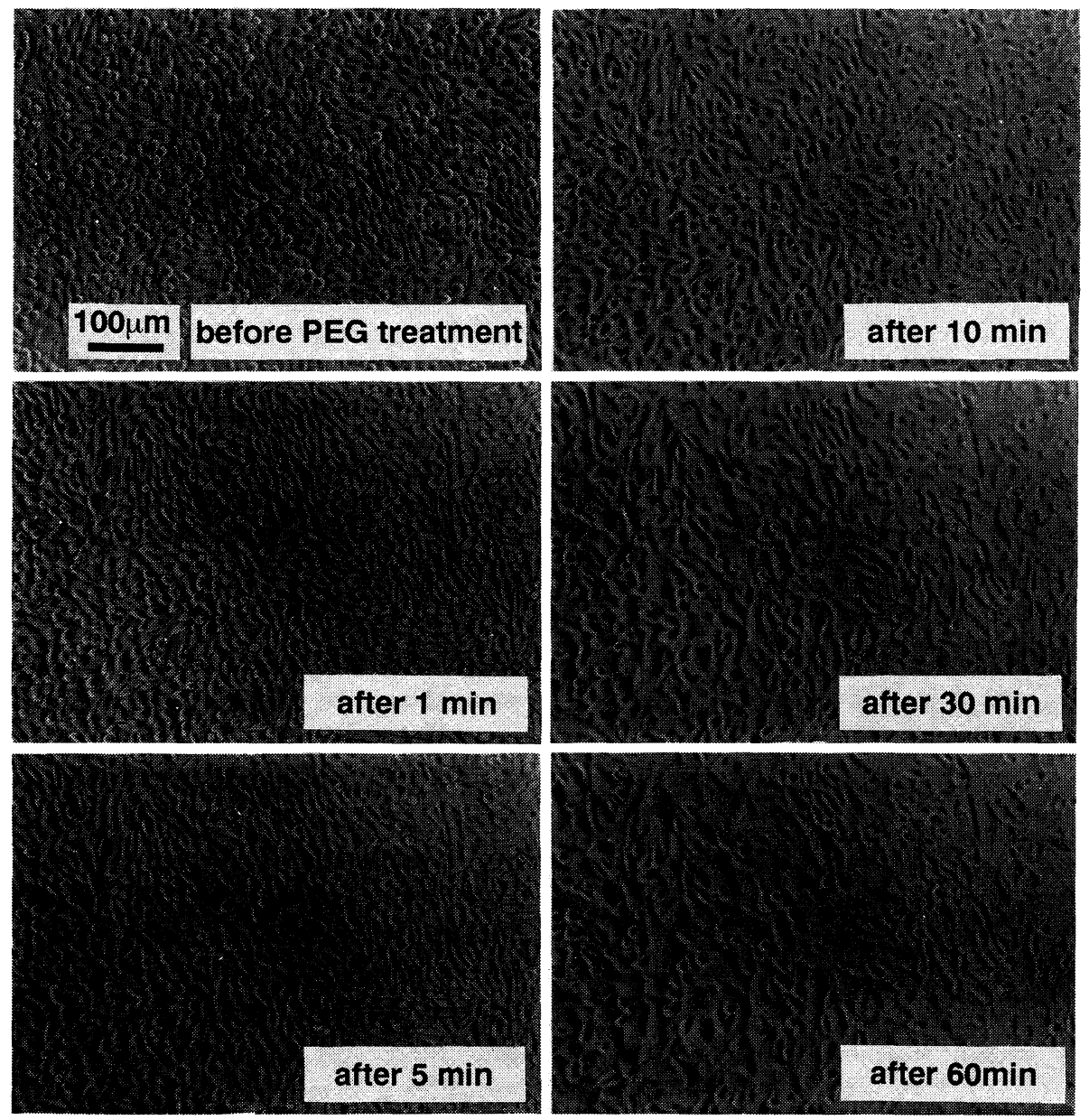

Figure 8. Phase-contrast micrographs of L929 cells exposured to PEG 3000 at $60 \mathrm{w} / \mathrm{w} \%$ for $1 \mathrm{~min}$ and then postincubated for different periods of time. Cell density: $1.5 \times 10^{5} \mathrm{cells}^{-2}$. The same field was photographed at room temperature except "before treatment".

did not show such strong fusion activity as 1000. The fusion index for L929 cells was generally higher than that for L cells, although there was no difference in the distance from cell to cell (no distinct difference in cell size for them was observed by picture analysis $(95 \%$ of reliance by the $t$-test)). Therefore, the fusogenic ability of PEG might be different from cell types. The relationship between the fusion index and binucleates fraction of all the fused cells is given in Figure 11 for L929 cells. Close correlation was observed between the two parameters, indicating that membrane fusion does not stop at the stage of binucleation but steadily advances to multinucleation.

\section{Effects of Molecular Weight Distribution of $P E G$}

PEG is usually synthesized from ethylene oxide by anionic living polymerization as in our case and hence the resulting polymer consists of almost monodispersed molecules, i.e., $\bar{M}_{w} / \bar{M}_{n}<1.10$. To study the effects of PEG molecular weight distribution on cell fusion, monodispersed PEG 400 and PEG 5000 were mixed to yield multidispersed PEG. $\bar{M}_{n}$ and 


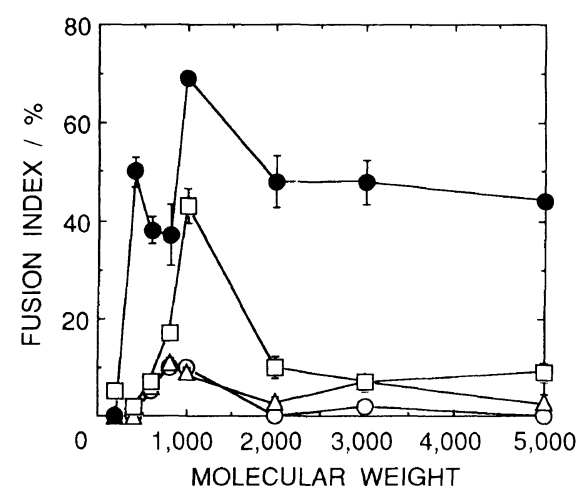

Figure 9. Effects of molecular weight and solution concentration of PEG on the fusion of L cells. Cell density, $1.5 \times 10^{5}$ cells cm $^{-2}$; exposure time, $1 \mathrm{~min}$; postincubation time, $2 \mathrm{~h}$. Error bars show the standard error $(n=6)$. (O), $30 ;(\triangle), 40 ;(\square), 50 ;(\bigcirc), 60 \mathrm{w} / \mathrm{w} \%$.

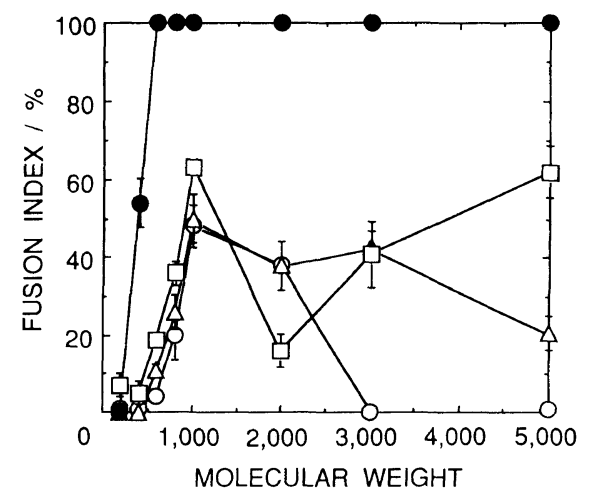

Figure 10. Effects of molecular weight and solution concentration of PEG on the fusion of L929 cells. Cell density, $1.5 \times 10^{5}$ cells cm $^{-2}$; exposure time, $1 \mathrm{~min}$; postincubation time, $2 \mathrm{~h}$. Error bars show the standard error $(n=6)$. (○), 30; $(\triangle), 40 ;(\square), 50 ;(\bigcirc), 60 \mathrm{w} / \mathrm{w} \%$.

$\bar{M}_{w}$ were calculated as follows:

$$
\begin{gathered}
\bar{M}_{n}=n_{\mathrm{p}}(\mathrm{L}) \times M_{w}(\mathrm{~L})+n_{\mathrm{p}}(\mathrm{H}) \times M_{w}(\mathrm{H}) \\
\bar{M}_{w}=w_{\mathrm{p}}(\mathrm{L}) \times M_{w}(\mathrm{~L})+w_{\mathrm{p}}(\mathrm{H}) \times M_{w}(\mathrm{H})
\end{gathered}
$$

where $M_{w}(\mathrm{~L}$ or $\mathrm{H})$ is the molecular weight of the monodispersed polymer (lower or higher molecular weight) before mixing, and $n_{\mathrm{p}}$ ( $\mathrm{L}$ or $\mathrm{H})$ and $w_{\mathrm{p}}(\mathrm{L}$ or $\mathrm{H})$ are the number and weight fraction of the polymer molecules (lower or higher molecular weight) in the mixture, respectively. Lower molecular-weight (L) PEG has $M_{w}$ of 400 and higher (H) PEG has $M_{w}$ of

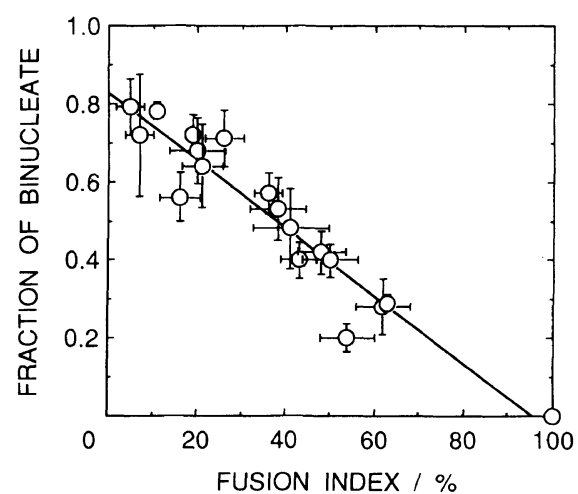

Figure 11. Relationship between fusion index and binucleate fraction of all the fused L929 cells. Fusion conditions were the same as in Figure 10. Error bars show the standard error $(n=6)$.

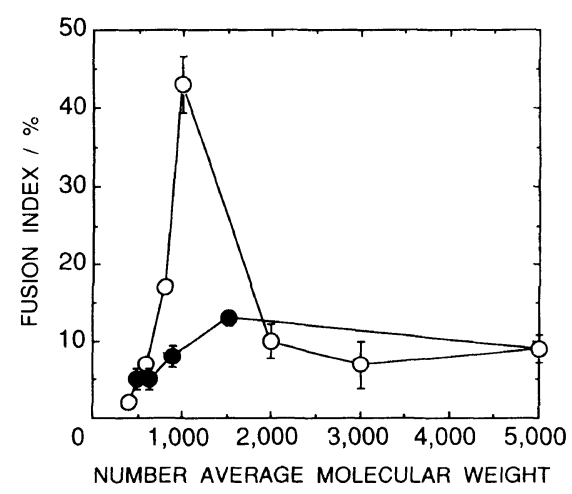

Figure 12. Comparison of monodispersed PEG and mixtures of PEG 400 and PEG 5000 at $50 \mathrm{w} / \mathrm{w} \%$ for the fusion of L cells. Fusion conditions were the same as in Figure 10. Error bars show the standard error $(n=6)$. (O) monodispersed PEG and (O) mixtures of PEG 400 and PEG 5000.

5000. The fusion index observed for $\mathrm{L}$ cells at $50 \mathrm{w} / \mathrm{w} \%$ PEG concentration is plotted against number-average molecular weight $\left(\bar{M}_{n}\right)$ in Figure 12. The monodispersed PEG showed quite a different profile from the mixed PEG. The finding that there was no concerted effect of low and high molecules indicates that effect of PEG molecular weight seen in Figures 9 and 10 is due to the intrinsic property of PEG with their own molecular weight. The plot for the weight-average molecular weight $\left(\bar{M}_{w}\right)$ showed 
results similar to those in Figure 12.

\section{DISCUSSION}

Davidson et al. studied the effects of molecular weight and solution concentration of PEG on the fusion of LM and 3T3 cells. ${ }^{6}$ In their report, the optimum molecular weight and concentration for cell fusion were 1000 and $50 \mathrm{w} / \mathrm{w} \%$, respectively, for both the cell lines. Our study showed that the peak molecular weight of PEG for cell fusion was approximately 1000 , but there was no optimum for PEG concentration. It is likely that the decrease of the hybridization frequency (or the fraction of binucleates) with increasing PEG concentration reported in their study was caused by overfusion. Excess membrane fusion often leads to cell death and thus with increasing PEG concentration the physicochemical interaction between PEG molecules and the cell membrane becomes stronger, resulting in higher fusion efficiency, although greater damage to the cell membrane may be induced at the same time.

Enhancement of cell fusion by higher cell density (Figure 4) may be due to increasing opportunity of contact between adjacent cells. Reduction in cell fusion at much higher cell density might be ascribed to decreased fluidity of the lipid bilayer in the membrane, perhaps due to biological junctions.

Honda et al. reported that cell fusion by PEG 6000 decreased or was completely prevented when the polymer was purified by reprecipitation from chloroform into diethyl ether or dialyzed against distilled water. ${ }^{39}$ They concluded that PEG itself had no fusogenic ability and that additives in commercial PEG were an essential for cell fusion. In contrast, Lucy et al. reported that PEG molecules are intrinsically fusogenic while additives merely enhance the frequency of fusion. ${ }^{14}$ This study using PEG containing no antioxidants shows that there is no difference in fusogenic activity before and after PEG treatment by repre- cipitation from the chloroform solution into diethyl ether and ethanol, or extraction with $n$-hexane. Therefore, it may be concluded that cell fusion by PEG is due to the intrinsic properties of PEG molecules.

We cannot explain why the optimum molecular weight of PEG was observed at around 1000 for the cell fusion, but this may be due to physicochemical properties related to the molecular weight of PEG such as toxicity, osmotic pressure and hydration power. For instance, very low molecular weight of PEG exhibits cytotoxicity, because it is likely that the low molecular weight of PEG would easily enters cells inside.

\section{REFERENCES}

1. M. A. Bratt and W. F. Gallaher, Proc. Natl. Acad. Sci. U.S.A., 64, 536 (1969).

2. S. Knutton and C. A. Pasternak, Trends Biochem. Sci., 4, 220 (1979).

3. C. Finaz, A. Lefevre, and J. Teissie, Exp. Cell Res., 150, 477 (1984).

4. T. J. Aldwinckle, Q. F. Ahkong, A. D. Bangham, D. Fisher, and J. A. Lucy, Biochim. Biophys. Acta, 689, 548 (1982).

5. K. Ahnold, A. Herrmann, L. Pratsch, and K. Gawrisch, Biochim. Biophys. Acta, 815, 515 (1985).

6. R. L. Davidson and P. S. Gelald, Somat. Cell Genet., 2, 165 (1976).

7. R. L. Davidson, K. A. O'Malley, and T. B. Wheeler, Somat. Cell Genet., 2, 271 (1976).

8. J. L. Kadish and K. M. Wenc, Hybridoma, 2, 87 (1983).

9. R. J. Klebe and M. G. Mancuso, Somat. Cell Genet., 7, 473 (1981).

10. R. D. Lane, R. S. Crissman, and M. F. Lachman, J. Immunol. Methods, 72, 71 (1984).

11. R. I. MacDonald, Biochemistry, 24, 4058 (1985).

12. S. Knutton, J. Cell Sci., 36, 61 (1979).

13. B. Maggio, Q. F. Ahkong, and J. A. Lucy, Biochem. J., 158, 647 (1976).

14. C. L. Smith, Q. F. Ahkong, D. Fisher, and J. A Lucy, Biochim. Biophys. Acta, 692, 109 (1982).

15. G. J. P. A. Anders, J. Werda, N. Nienhaus, and V. J. S. Idenburg, Hum. Genet., 42, 319 (1978).

16. C. Brahe and A. Serra, Somat. Cell Genet., 7, 109 (1981).

17. A. Hales, Somat. Cell Genet., 3, 227 (1977).

18. J. Kajstura and W. Korohoda, Fol. Histchem. Cytobiol., 26, 77 (1988).

19. K. N. Kao and M. R. Michayluk, Planta, 115, 355 
(1974)

20. T. H. Norwood, C. J. Ziegler, and G. M. Martin, Somat. Cell Genet., 2, 263 (1976).

21. P. S. Rabinovitch and T. H. Norwood, Somat. Cell Genet., 7, 281 (1981).

22. S. Schneiderman, J. L. Farber, and R. Baserga, Somat. Cell Genet., 5, 263 (1979).

23. Q. F. Ahkong, D. Fisher, W. Tampion, and J. A. Lucy, Biochem. J., 136, 147 (1973).

24. M. Wakahara, Exp. Cell Res., 128, 9 (1980).

25. M. Hollenberg, N. Honbo, Q. P. Ghani, and A. J. Samorodin, J. Cellular Physiol., 106, 209 (1981).

26. K. Hong, F. Schuber, and D. Papahadjopoulos, Biochim. Biophys. Acta, 732, 469 (1983).

27. Y. Matsuya and I. Yamane, J. Cell Sci., 78, 273 (1985).

28. N. Oku, N. Yamaguchi, N. Yamaguchi, S. Shibamoto, F. Ito, and M. Nango, J. Biochem., 100, 935 (1986).

29. B. Maggio and J. A. Lucy, Biochem. J., 155, 353 (1986).

30. M. Yamazaki and T. Ito, Biochemistry, 29, 1309
(1990).

31. L. T. Boni, J. S. Hah, S. W. Hui, P. Mukherjee, J. T. Ho, and C. Y. Jung, Biochim. Biophys. Acta, 775, 409 (1984).

32. D. S. Roos, J. M. Robinson, and R. L. Davidson, J. Cell Biol., 97, 909 (1983).

33. Q. F. Ahkong, J. P. Desmazes, D. Georgescauld, and J. A. Lucy, J. Cell Sci., 88, 389 (1987).

34. D. Hoekstra, Exp. Cell Res., 144, 482 (1983).

35. J. W. Wojcieszyn, R. A. Schlegel, K. LumleySapanski, and K. A. Jacobson, J. Cell Biol., 96, 151 (1983).

36. W. F. Boss, Biochim. Biophys. Acta, 730, 111 (1983).

37. K. Arnold, O. Zschoering, D. Barthel, and W. Herold, Biochim. Biophys. Acta, 1022, 303 (1990).

38. A. M. J. Blow, G. M. Botham, D. Fisher, A. H. Goodall, C. P. S. Tilcock, and J. A. Lucy, FEBS Lett., 94, 30 (1978).

39. K. Honda, Y. Maeda, S. Sasakawa, H. Ohno, and E. Tsuchida, Biochem. Biophys. Res. Commun., 101, 165 (1981). 